\title{
ANALISIS PERBANDINGAN JUMLAH USAHA INDUSTRI DAN PENYERAPAN TENAGA KERJA TERHADAP PERTUMBUHAN EKONOMI
}

\author{
ZULAIKA MATONDANG, M.Si \\ IAIN PADANGSIDIMPUAN \\ Jalan T. Rizal Nurdin Km. 4,5 Sihitang, Padangsidimpuan \\ E-mail: zulaikamatondang83@gmail.com
}

\begin{abstract}
ABSTRAK,
Latar belakang masalah dalam penelitian ini adalah terdapatnya fenomena peningkatan pertumbuhan ekonomi (PDRB) pada saat jumlah usaha industri dan penyerapan tenaga kerja mengalami fluktuasi yang tidak sesuai dengan teori. Rumusan penelitian ini adalah apakah ada pengaruh jumlah usaha industri dan penyerapan tenaga kerja terhadap pertumbuhan ekonomi secara parsial maupun simultan dan apakah terdapat perbedaan pengaruh antara jumlah usaha industri dan penyerapan tenaga kerja terhadap pertumbuhan ekonomi di Provinsi Sumatera Utara dan Provinsi Sumatera Barat. Penelitian ini merupakan penelitian kuantitatif deskriptif. Sampel yang digunakan sebanyak 32 sampel dengan desain simple random sampling, data diperoleh melalui situs www.bps.go.id. Pengujian dalam penelitian ini menggunakan program komputer SPSS versi 23. Hasil penelitian menunjukkan bahwa secara parsial variabel jumlah usaha industri tidak memiliki pengaruh terhadap pertumbuhan ekonomi, di Provinsi Sumatera Utara karena. Dilihat dari grafik plot repeated measure dapat dinyatakan pengaruh jumlah usaha industri dan penyerapan tenaga kerja terhadap pertumbuhan ekonomi tidak efektif di Provinsi Sumatera Utara, namun efektif di Provinsi Sumatera Barat. Pengaruh jumlah usaha industri dan penyerapan tenaga kerja terhadap pertumbuhan ekonomi di Provinsi Sumatera Barat sebesar 0,6\% sedangkan sisanya sebesar 99,4\% dipengaruhi faktor lain yang tidak dimasukkan dalam penelitian, sedangkan di Provinsi Sumatera Barat sebesar $68,9 \%$ dan sisanya sebesar $31,1 \%$ dipengaruhi faktor lain yang tidak dimasukkan dalam penelitian.
\end{abstract}

\section{Kata Kunci: Jumlah Usaha Industri, PDRB}

\begin{abstract}
ABSTRAK,
The background of the problem in this study is the existence of the phenomenon of increasing economic growth (GRDP) when the number of industrial businesses and employment absorbed fluctuations that were not in accordance with the theory. The formulation of this study is whether there is an influence of the number of industrial businesses and employment of economic growth partially or simultaneously and whether there are differences in influence between the number of industrial businesses and employment of economic growth in the provinces of North Sumatra and West Sumatra Province. This research is descriptive quantitative research. The sample used was 32 samples with a simple random sampling design, the data obtained through the site www.bps.go.id. The test in this study uses the SPSS version 23. computer program The results of the study show that partially the variable number of industrial businesses has no influence on economic growth, because
\end{abstract}




\section{ANALISIS PERBANDINGAN JUMLAH USAHA INDUSTRI DAN \\ PENYERAPAN TENAGA KERJA TERHADAP \\ PERTUMBUHAN EKONOMI}

ZULAIKA MATONDANG, M.Si

of North Sumatra Province. Judging from the repeated measure plot graph, it can be stated the effect of the number of industrial businesses and labor absorption on economic growth is not effective in North Sumatra Province, but effective in the Province of West Sumatra. The influence of the number of industrial businesses and employment on economic growth in West Sumatra Province is $0.6 \%$ while the remaining $99.4 \%$ is influenced by other factors not included in the study, while in West Sumatra Province $68.9 \%$ and the remaining $31,1 \%$ is influenced by other factors not included in the study.

\section{Keywords: Number of Industrial Businesses, PDRB}

\section{PENDAHULUAN}

Indonesia memiliki beberapa Provinsi di antaranya adalah Provinsi Sumatera Utara dan Provinsi Sumatera Barat. Kedua Provinsi tersebut memiliki demografi, geografi dan sektor unggulan yang hampir sama yakni salah satunya pada sektor pertanian. Provinsi Sumatera Utara memiliki laju pertumbuhan penduduk dari tahun 2000-2010 sebesar 1,10 persen. Perekonomian Sumatera Utara pada tahun 2014 tumbuh sebesar 5,23 persen, menurun dibandingkan tahun 2013yang sebesar 6,08 dengan PDRB perkapita tahun 2014 sebesar Rp38,05 juta.

Sedangkan di Provinsi Sumatera Barat sendiri berdasarkan sensus penduduk tahun 2010, jumlah populasi Sumatera Barat mencapai 4.846.909 jiwa, dengan kepadatan penduduk sebanyak $110 \mathrm{jiwa} / \mathrm{km} 2$. Perekonomian Sumatera Barat tahun 2014 sebesar 5,85 persen, juga mengalami penurunan pada tahun 2013 yang mencapai 6,02 persen dengan PDRB perkapita tahun 2014 sebesar Rp32,55 juta.

Melihat kondisi perekonomian di kedua wilayah tersebut, industri sedang dan besar yang dapat menyerap banyak tenaga kerja juga ikut berperan dalam meningkatkan laju pertumbuhan ekonomi. Berdasarkan Badan Pusat Statistik diperoleh data perbandingan jumlah usaha industri di Provinsi Sumatera Utara dan Provinsi Sumatera Barat tahun 2000-2015 sebagai berikut: 
Perbandingan Jumlah Usaha Industri diProvinsi Sumatera Utara dan Provinsi Sumatera Barat tahun 2000-2015

\begin{tabular}{|c|c|c|}
\hline \multirow{2}{*}{ Tahun } & \multicolumn{2}{|c|}{ Jumlah Usaha Industri (Unit) } \\
\cline { 2 - 3 } & Provinsi Sumatera Utara & Provinsi Sumatera Barat \\
\hline 2000 & 1.001 & 143 \\
\hline 2001 & 959 & 157 \\
\hline 2002 & 967 & 158 \\
\hline 2003 & 919 & 152 \\
\hline 2004 & 929 & 151 \\
\hline 2005 & 966 & 138 \\
\hline 2006 & 1.218 & 180 \\
\hline 2007 & 1.181 & 178 \\
\hline 2008 & 1.145 & 182 \\
\hline 2009 & 1.109 & 158 \\
\hline 2010 & 1.002 & 139 \\
\hline 2011 & 987 & 135 \\
\hline 2012 & 1.023 & 145 \\
\hline 2013 & 1.006 & 140 \\
\hline 2014 & 1.012 & 143 \\
\hline 2015 & 960 & 162 \\
\hline
\end{tabular}

Sumber: BPS Provinsi Sumatera Utara dan Provinsi Sumatera Barat

Dari data di atas terlihat jelas perbandingan usaha industri di Provinsi Sumatera Utara dan Provinsi Sumatera Barat tahun 2000-2015 mengalami fluktuasi. Seharusnya besarnya jumlah usaha industri sangat menentukan banyaknya jumlah tenaga kerja yang bekerja pada usaha industri tersebut. Namun, nyataanya berbeda dengan teori yang ada. Justru mengalami fluktuasi berlawanan dengan teori. Dilihat dari pertumbuhan ekonomi pada sektor industri perbandingannya dapat dilihat dari perkembangan Produk Domestik Regional Bruto (PDRB) pada Badan Pusat Statistikdi Provinsi Sumatera Utara dan Provinsi Sumatera Barat tahun 2000-2015 sebagai berikut: 
ANALISIS PERBANDINGAN JUMLAH USAHA INDUSTRI DAN

PENYERAPAN TENAGA KERJA TERHADAP

PERTUMBUHAN EKONOMI

ZULAIKA MATONDANG, M.Si

Perbandingan Jumlah PDRB diProvinsi Sumatera Utara dan

Provinsi Sumatera Barat tahun 2000-2014

\begin{tabular}{|c|c|c|}
\hline \multirow{2}{*}{ Tahun } & \multicolumn{2}{|c|}{ PDRB (Miliar/Billion Rp) } \\
\cline { 2 - 3 } & Provinsi Sumatera Utara & Provinsi Sumatera Barat \\
\hline 2000 & 5.160 .550 & 3.218 .470 \\
\hline 2001 & 5.391 .970 & 3.318 .632 \\
\hline 2002 & 5.783 .310 & 3.404 .309 \\
\hline 2003 & 19.298 .240 & 3.472 .186 \\
\hline 2004 & 20.337 .030 & 3.629 .456 \\
\hline 2005 & 21.305 .370 & 3.808 .287 \\
\hline 2006 & 22.470 .570 & 3.978 .641 \\
\hline 2007 & 23.615 .200 & 4.209 .069 \\
\hline 2008 & 24.305 .230 & 4.509 .531 \\
\hline 2009 & 24.977 .110 & 4.670 .605 \\
\hline 2010 & 26.105 .610 & 4.787 .848 \\
\hline 2011 & 26.548 .660 & 5.010 .656 \\
\hline 2012 & 76.922 .410 & 13.690 .474 \\
\hline 2013 & 80.648 .620 & 14.393 .981 \\
\hline 2014 & 83.042 .090 & 15.171 .749 \\
\hline 2015 & 86.081 .400 & 15.418 .540 \\
\hline
\end{tabular}

Sumber: BPS Provinsi Sumatera Utara dan Provinsi Sumatera Barat

Hal tersebut mengartikan terdapat hubungan yang positif antara jumlah usaha industri dan penyerapan tenaga kerja industri terhadap pertumbuhan ekonomi Maka peneliti ingin mengetahui apa yang melatarbelakangi hal tersebut dan akan membandingkannya.

\section{LANDASAN TEORI}

\section{Pengertian Usaha Industri}

Usaha adalah kegiatan di bidang perdagangan dengan maksud mencari untung. Sedangkan yang dimaksud dengan industri adalah kumpulan dari semua perusahaan yang menghasilkan barang yang sama (Iskandar Putong, 2005). Jadi usaha industri adalah kegiatan di bidang perdagangan dengan maksud mencari untung yang dilakukan oleh kumpulan dari semua perusahaan yang menggunakan atau memanfaatkan dan mengorganisasi faktor-faktor produksi.Dengan demikian, industri merupakan bagian dari proses produksi. Bahan-bahan industri diambil 
secara langsung maupun tidak langsung, kemudian diolah, sehingga menghasilkan barang yang bernilai lebih bagi masyarakat. Kegiatan proses produksi dalam industri itu disebut dengan perindustrian.Beberapa hal yang digolongkan dalam bidang industri adalah industri pengolahan (manufactrure), industri pariwisata, industri hiburan, industri pendidikan dan lain-lain.

\section{Kebijakan Industri}

Pembuat kebijakan masih berdebat apakah pemerintah federal harus lebih terlibat dalam membentuk masa depan teknologi negara atau tidak. Salah satu pertimbangannya adalah bahwa teknologi masa depan memerlukan sejumlah modal besar untuk pengembangan dan implementasinya. Jumlah tersebut biasanya tidak dapat dipenuhi oleh satu perusahaan saja. Pertimbangan lainnya adalah bahwa beberapa terobosan teknologi bermanfaat bagi perusahaan atau industri lain, tetapi perusahaan yang mengembangkan teknologi tersebut tidak dalam posisi untuk memperoleh keuntungan dari manfaat yang dinikmati oleh pihak lain. Hal ini menyebabkan perusahaan tidak terdorong untuk berinvestasi dalam terobosan teknologi semacam itu.Salah satu solusi yang mungkin dari masalah tersebut adalah campur tangan pemerintah.

Kebijakan industri adalah ide bahwa pemerintah, dengan menggunakan pajak, subsidi, peraturan dan koordinasi, seharusnya membantu pengembangan industri dan teknologi masa depan, sehingga industri dalam negeri bisa lebih unggul dibandingkan luar negeri. Tujuannya adalah untuk mempertahankan kepemimpinan industri dalam negeri(William A. McEachern, 2000).

\section{Operasi Perusahaan dan Industri dalam Jangka Panjang}

Dalam jangka panjang perusahaan dan industri dapat membuat beberapa perubahan tertentu yang di dalam jangka pendek tidak dapat dilakukan.Perusahaan dapat menambah faktor-faktor produksi yang di dalam jangka pendek adalah tetap jumlahnya.Kemungkinan ini menyebabkan perusahaan tidak lagi mengeluarkan biaya tetap.Semuanya adalah biaya berubah. Seterusnya keadaan dalam industri juga mengalami perubahan, yaitu perusahaanperusahaan baru akan memasuki industri dan beberapa perusahaan lama yang tidak efisien akan gulung tikar dan meninggalkan industri. Perubahan seperti ini 


\section{ANALISIS PERBANDINGAN JUMLAH USAHA INDUSTRI DAN \\ PENYERAPAN TENAGA KERJA TERHADAP \\ PERTUMBUHAN EKONOMI}

ZULAIKA MATONDANG, M.Si

tidak berlaku dalam jangka pendek. Telah dinyatakan apabila sesuatu perusahaan tidak dapat menutupi biaya berubahnya, ia tidak akan membubarkan usahanya tetapi hanya akan menghentikan kegiatan produksinya. Perubahan lain yang mungkin berlaku dalam jangka panjang adalah teknologi, kenaikan upah tenaga kerja dan kenaikan harga-harga umum (inflasi). Perubahan ini akan mempengaruhi biaya produksi di setiap perusahaan (Sadono Sukirno, 2005).

\section{Penyerapan Tenaga Kerja}

\section{Pengertian Penyerapan Tenaga Kerja}

Tenaga kerja manusia adalah segala kegiatan manusia baik jasmani maupun rohani yang dicurahkan dalam proses produksi untuk menghasilkan barang dan jasa maupun faedah suatu barang. Sedangkan penyerapan tenaga kerja merupakan jumlah tertentu dari tenaga kerja yang digunakan dalam suatu unit usaha tertentu atau dengan kata lain penyerapan tenaga kerja adalah jumlah tenaga kerja yang bekerja dalam suatu unit usaha. Tenaga kerja merupakan faktor produksi yang diakui oleh setiap sistem ekonomi baik ekonomi Islam, Kapitalis dan Sosialis. Tenaga kerja manusia dapat diklasifikasikan menurut tingkatannya (kualitasnya) yang terbagi atas (Rozalinda, 2014):

Pertama, tenaga kerja terdidik (skilled labour), adalah tenaga kerja yang memperoleh pendidikan baik formal maupun nonformal, seperti guru, dokter, pengacara, akuntan, psikologi, peneliti dan lain-lain.

Kedua, tenaga kerja terlatih (trained labour), adalah tenaga kerja yang memperoleh keahlian berdasarkan latihan dan pengalaman. Misalnya, montir, tukang kayu, tukang ukir, sopir, teknisi dan lain-lain.

Tiga, tenaga kerja tak terdidik dan tak terlatih (unskilled and untrained labour), adalah tenaga kerja yang mengandalkan kekuatan jasmani daripada ruhani, seperti tenaga kuli pikul, tukang sapu, pemulung, buruh tani dan lain-lain.

\section{METODE PENELITIAN}

Jenis penelitian ini adalah penelitian kuantitatif deskriptif, dengan populasi dalam berjumlah 32 tahun, meliputi seluruh data jumlah industri, tenaga kerja industri dan pertumbuhan ekonomi Provinsi Sumatera Utara dan Provinsi Sumatera Barat yang dipublikasikan oleh Badan Pusat Statistik tahun 2000-2015. 
Untuk menentukan sampel dilakukan dengan teknik simple random sampling. Sehingga sampel yang diambil dalam penelitian ini adalah data jumlah industri, tenaga kerja industri dan pertumbuhan ekonomi Provinsi Sumatera Utara dan Provinsi Sumatera Barat tahun 2000-2015 sehingga keseluruhan mencapai 32 sampel. Teknik analisis datanya yaitu, Analisis Deskriptif, Uji Normalitas, Uji Linieritas, Uji Asumsi Klasik, Uji Multikolinieritas, Uji Heterokedastisitas, Uji Autokorelasi, Analisis Regresi Linier Berganda, Uji Hipotesis.

\section{HASIL PENELITIAN}

\section{Hasil Analisis Deskriptif}

Adapun analisis deskriptif dalam penelitian ini menggunakan menu deskriptif dengan hasil sebagai berikut:

Hasil Analisis Deskriptif

\begin{tabular}{|c|c|c|c|c|c|c|c|c|c|}
\hline \multirow[b]{2}{*}{ VARIABEL } & \multicolumn{5}{|c|}{ Provinsi Sumatera Utara } & \multicolumn{4}{|c|}{ Provinsi Sumatera Barat } \\
\hline & $\mathrm{N}$ & Min & $\operatorname{Max}$ & Mean & Std. Deviation & Min & Max & Mean & Std. Deviation \\
\hline JUI & & & & & & & & & \\
\hline & 16 & 919 & 1218 & 1024,94 & 90,125 & 135 & 182 & 153,81 & 15,307 \\
\hline PTK & 16 & $\begin{array}{r}143 \\
553 \\
\end{array}$ & $\begin{array}{r}16691 \\
3 \\
\end{array}$ & $\begin{array}{r}155205, \\
81 \\
\end{array}$ & 7858,806 & $\begin{array}{r}148 \\
02 \\
\end{array}$ & 27045 & 19736,25 & 3871,922 \\
\hline $\mathrm{PE}$ & 16 & $\begin{array}{r}516 \\
055 \\
0\end{array}$ & $\begin{array}{r}86081 \\
400\end{array}$ & $\begin{array}{r}3449958 \\
5,63\end{array}$ & 29070415,946 & $\begin{array}{r}321 \\
847 \\
0\end{array}$ & $\begin{array}{r}15418 \\
540\end{array}$ & 6668277,13 & 4813135,405 \\
\hline Valid N & 16 & & & & & & & & \\
\hline
\end{tabular}

Sumber: OutputSPSSVersi23, data diolah

Data menunjukkan bahwa jumlah sampel (N) sebanyak 32 sampel. 16 sampel di Provinsi Sumatera Utara dan 16 sampel di Provinsi Sumatera Barat. Jumlah usaha industri di Provinsi Sumatera Utara memiliki nilai minimum sebesar 919 dan maksimum 1218,. nilai rata-rata 1024,94 dan standar deviasi sebesar 90,125, Penyerapan tenaga kerja di Provinsi Sumatera Utara memiliki nilai minimum 143553 dan nilai maksimum adalah sebesar 166913, nilai rata-rata 155205,81 dan standar deviasi 7858,806. Pertumbuhan ekonomi memiliki nilai 


\section{ANALISIS PERBANDINGAN JUMLAH USAHA INDUSTRI DAN \\ PENYERAPAN TENAGA KERJA TERHADAP \\ PERTUMBUHAN EKONOMI}

ZULAIKA MATONDANG, M.Si

minimum $5160550 \%$ dan nilai maksimum sebesar 83042090 , nilai rata-rata sebesar 34499585,63 dan standar deviasi sebesar 29070415,946.

Sedangkan jumlah usaha industri di Provinsi Sumatera Barat memiliki nilai minimun sebesar 135 dan maksimum 182, nilai rata-rata 153,81 dan standar deviasi sebesar 15,307. Penyerapan tenaga kerja di Provinsi Sumatera Barat memiliki nilai minimum 14802 dan nilai maksimum adalah sebesar 27045, nilai rata-rata 19736,25 dan standar deviasi 3871,922. Pertumbuhan ekonomi memiliki nilai minimum 3218470 dan nilai maksimum sebesar 15418540, nilai rata-rata sebesar 6668277,13 dan standar deviasi sebesar 4813135,405.

\section{Uji Normalitas}

Hasil uji normalitas dapat dilihat sebagai berikut:

Uji Normalitas

\begin{tabular}{|c|c|c|c|c|c|c|c|}
\hline \multicolumn{8}{|c|}{ One-Sample Kolmogorov-Smirnov Test } \\
\hline & & \multicolumn{3}{|c|}{ Provinsi Sumatera Utara } & \multicolumn{3}{|c|}{ Provinsi Sumatera Barat } \\
\hline & & JUI & PTK & $\mathrm{PE}$ & JUI & PTK & PE \\
\hline \multicolumn{2}{|l|}{$\mathrm{N}$} & 16 & 16 & 16 & 16 & 16 & 16 \\
\hline \multirow{2}{*}{$\begin{array}{l}\text { Normal } \\
\text { Parameters }{ }^{\mathrm{a}, \mathrm{b}}\end{array}$} & Mean & 1024,94 & 155205,81 & 34499585,63 & 153,81 & 19736,25 & 6668277,13 \\
\hline & $\begin{array}{l}\text { Std. } \\
\text { Deviation }\end{array}$ & 90,125 & 7858,806 & 29070415,946 & 15,307 & 3871,922 & 4813135,405 \\
\hline \multirow{3}{*}{$\begin{array}{l}\text { Most } \\
\text { Extreme } \\
\text { Differences }\end{array}$} & Absolute & ,241 & ,168 & ,358 & ,155 & ,260 & ,385 \\
\hline & Positive & ,241 & , 168 & ,358 &, 155 & ,260 & ,385 \\
\hline & Negative &,- 120 &,- 130 &,- 178 &,- 130 &,- 145 &,- 237 \\
\hline \multicolumn{2}{|l|}{ Test Statistic } & ,241 & ,168 & ,358 & ,155 & ,260 & ,385 \\
\hline \multicolumn{2}{|c|}{ Asymp. Sig. (2-tailed) } &, $014^{\mathrm{c}}$ & $200^{\mathrm{c}, \mathrm{d}}$ &, $000^{c}$ & $200^{\mathrm{c}, \mathrm{d}}$ &, $005^{\mathrm{c}, \mathrm{d}}$ &, $000^{\mathrm{c}}$ \\
\hline
\end{tabular}

Sumber: OutputSPSSVersi 23, data diolah

Berdasarkan tabel IV.2 di atas terlihat bahwa nilai probability (Test Statistic atau Absolute) jumlah usaha industri, penyerapan tenaga kerja dan pertumbuhan ekonomi di Provinsi Sumatera Utara lebih besar dari 0,05 (0,241 > 0,05), (0,168 > 0,05), (0,358 > 0,05). Dan nilai probability (Test Statistic atau Absolute) jumlah usaha industri, penyerapan tenaga kerja dan pertumbuhan ekonomi di Provinsi Sumatera Barat juga lebih besar dari 0,05 (0,155>0,05), $(0,260>0,05),(0,385>$ 
0,05). Jadi, dapat disimpulkan bahwa data berdistribusi normal dengan menggunakan uji Kolmogorov Smirnov.

\section{Uji Linieritas}

Hasil uji linieritas dapat dilihat sebagai berikut:

Uji Linieritas

\begin{tabular}{|l|l|l|r|r|}
\hline \multicolumn{2}{|c|}{ ANOVA Table } \\
\hline PE * & Between Groups & (Combined) & \multicolumn{1}{|c|}{ F } & Sig. \\
\hline JUI* & \multicolumn{1}{|c|}{ Linearity } & 18,280 & 0,053 \\
\hline PTK & & Deviation from Linearity & 13,052 & $\mathbf{0 , 0 0 6}$ \\
\hline & Within Groups & & & 0,074 \\
\hline & Total & & & \\
\hline
\end{tabular}

Sumber: OutputSPSS Versi 23, data diolah

Berdasarkan tabel IV.3 di atas terlihat bahwa nilai signifikansi linearity adalah 0,008 dan kurang dari 0,05 (0,006<0,05). Jadi dapat disimpulkan bahwa variabel jumlah usaha industri, penyerapan tenaga kerja dan pertumbuhan ekonomi di Provinsi Sumatera Utara dan Provinsi Sumatera Barat memiliki hubungan yang linier.

\section{Uji Asumsi Klasik}

Uji asumsi klasik dilakukan untuk mendeteksi apakah terdapat multikolinieritas, autokorelasi dan heterokedastisitas.

\section{Uji Multikolinieritas}

Hasil dari uji multikolinieritas dapat dilihat sebagai berikut:

\section{Uji Multikolinieritas}

Coefficients $^{\mathrm{a}}$

\begin{tabular}{|c|c|c|c|c|c|}
\hline \multicolumn{2}{|c|}{ Model } & \multicolumn{3}{|c|}{ Provinsi Sumatera Utara } & \multicolumn{2}{c|}{ Provinsi Sumatera Barat } \\
\cline { 3 - 6 } & Tolerance & VIF & Tolerance & VIF \\
\cline { 2 - 6 } & (Constant) & & & & 0,993 \\
\cline { 2 - 6 } 1 & JUI & 0,995 & 1,005 & 0,993 & 1,007 \\
\cline { 2 - 6 } & PTK & 0,995 & 1,005 & & 1,007 \\
\hline
\end{tabular}

Sumber: Output SPSS Versi 23, data diolah 


\section{ANALISIS PERBANDINGAN JUMLAH USAHA INDUSTRI DAN \\ PENYERAPAN TENAGA KERJA TERHADAP \\ PERTUMBUHAN EKONOMI}

ZULAIKA MATONDANG, M.Si

Berdasarkan tabel IV.4 di Provinsi Sumatera Utara dapat diketahui nilai VIF dari variabel jumlah usaha industri dan penyerapan tenaga kerja lebih kecil dari 10 $(1,005<10)$, dan nilai tolerance dari variabel jumlah usaha industri dan variabel penyerapantenaga kerja lebih besar dari $0,10(0,995<0,10)$, artinya tidak terjadi multikolinearitas terhadap data yang diuji. Sedangkan di Provinsi Sumatera Barat dapat diketahui nilai VIF dari variabel jumlah usaha industri dan penyerapan tenaga kerja lebih kecil dari $10(1,007<10)$, dan nilai tolerance dari variabel jumlah usaha industri dan variabel penyerapan tenaga kerja lebih besar dari 0,10 $(0,993<0,10)$, artinya tidak terjadi multikolinearitas terhadap data yang

\section{Uji Heterokedastisitas}

Hasil uji heterokedastisitas dapat dilihat sebagai berikut:

Uji Heterokedastisitas

\begin{tabular}{|c|c|c|c|c|c|c|c|c|}
\hline \multicolumn{9}{|c|}{ Correlations } \\
\hline & & & \multicolumn{3}{|c|}{$\begin{array}{c}\text { Provinsi Sumatera } \\
\text { Utara }\end{array}$} & \multicolumn{3}{|c|}{$\begin{array}{c}\text { Provinsi Sumatera } \\
\text { Barat }\end{array}$} \\
\hline & & & JUI & PTK & $\begin{array}{c}\text { Unstandardized } \\
\text { Residual }\end{array}$ & JUI & PTK & $\begin{array}{c}\text { Unstandardized } \\
\text { Residual }\end{array}$ \\
\hline \multirow[t]{9}{*}{$\begin{array}{l}\text { Spearman's } \\
\text { rho }\end{array}$} & JUI & $\begin{array}{l}\text { Correlation } \\
\text { Coefficient }\end{array}$ & 1,000 &,- 015 &, 359 & 1,000 & ,203 &,- 007 \\
\hline & & Sig. (2-tailed) & & ,957 & ,172 & & , 450 & ,978 \\
\hline & & $\mathrm{N}$ & 16 & 16 & 16 & 16 & 16 & 16 \\
\hline & PTK & $\begin{array}{l}\text { Correlation } \\
\text { Coefficient }\end{array}$ &,- 015 & 1,000 &,- 324 & ,203 & 1,000 &,- 032 \\
\hline & & Sig. (2-tailed) & ,957 & & ,222 & ,450 & $\cdot$ & ,905 \\
\hline & & $\mathrm{N}$ & 16 & 16 & 16 & 16 & 16 & 16 \\
\hline & $\begin{array}{l}\text { Unstandar } \\
\text { dized }\end{array}$ & $\begin{array}{l}\text { Correlation } \\
\text { Coefficient }\end{array}$ & ,359 &,- 324 & 1,000 &,- 007 &,- 032 & 1,000 \\
\hline & Residual & Sig. (2-tailed) & ,172 & ,222 & . & ,978 & ,905 & \\
\hline & & $\mathrm{N}$ & 16 & 16 & 16 & 16 & 16 & 16 \\
\hline
\end{tabular}

Sumber:Hasil OutputSPSS Versi 23, data diolah

Berdasarkan tabel IV.5 di Provinsi Sumatera Utara dapat dilihat bahwa nilai signifikansi dari jumlah usaha industri lebih besar dari $0,05(0,172>0,05)$. Kemudian nilai signifikansi penyerapan tenaga kerja lebih besar dari 0,05 (0,222> 0,05). Juga di Provinsi Sumatera Barat dapat dilihat bahwa nilai signifikansi dari 
jumlah usaha industri lebih besar dari $0,05(0,978>0,05)$. Kemudian nilai signifikansi penyerapan tenaga kerja lebih besar dari 0,05 (0,905>0,05). Jadi dapat disimpulkan bahwa tidak terjadi masalah heterokedastisitas pada model regresi.

\section{Uji Autokorelasi}

Hasil uji autokorelasi dapat dilihat sebagai berikut:

\section{Uji Autokorelasi}

\begin{tabular}{|c|c|c|c|}
\hline \multicolumn{4}{|c|}{ Model Summary $^{\mathbf{b}}$} \\
\hline \multicolumn{3}{|c|}{ Provinsi Sumatera Utara } & \multicolumn{2}{|c|}{ Provinsi Sumatera Barat } \\
\hline Model & Durbin-Watson & Model & Durbin-Watson \\
\hline 1 & 0,215 & 1 & 0,543 \\
\hline
\end{tabular}

Sumber: OutputSPSS Versi 23, data diolah

Berdasarkan tabel IV.6 di Provinsi Sumatera Utara diketahui nilai Durbin Watson sebesar 0,215. Artinya tidak terjadi autokorelasi karena lebih besar dari -2 dan lebih kecil dari $+2(-2<0,215<+2)$. Sedangkan di Provinsi Sumatera Barat diketahui nilai Durbin Watson sebesar 0,543. Artinya tidak terjadi autokorelasi kerena lebih besar dari -2 dan lebih kecil dari $+2(-2<0,543<+2)$.

\section{Analisis Regresi Linier berganda}

Adapun hasil uji regresi linier berganda dapat dilihat sebagai berikut:

Hasil Uji Regresi Linear Berganda

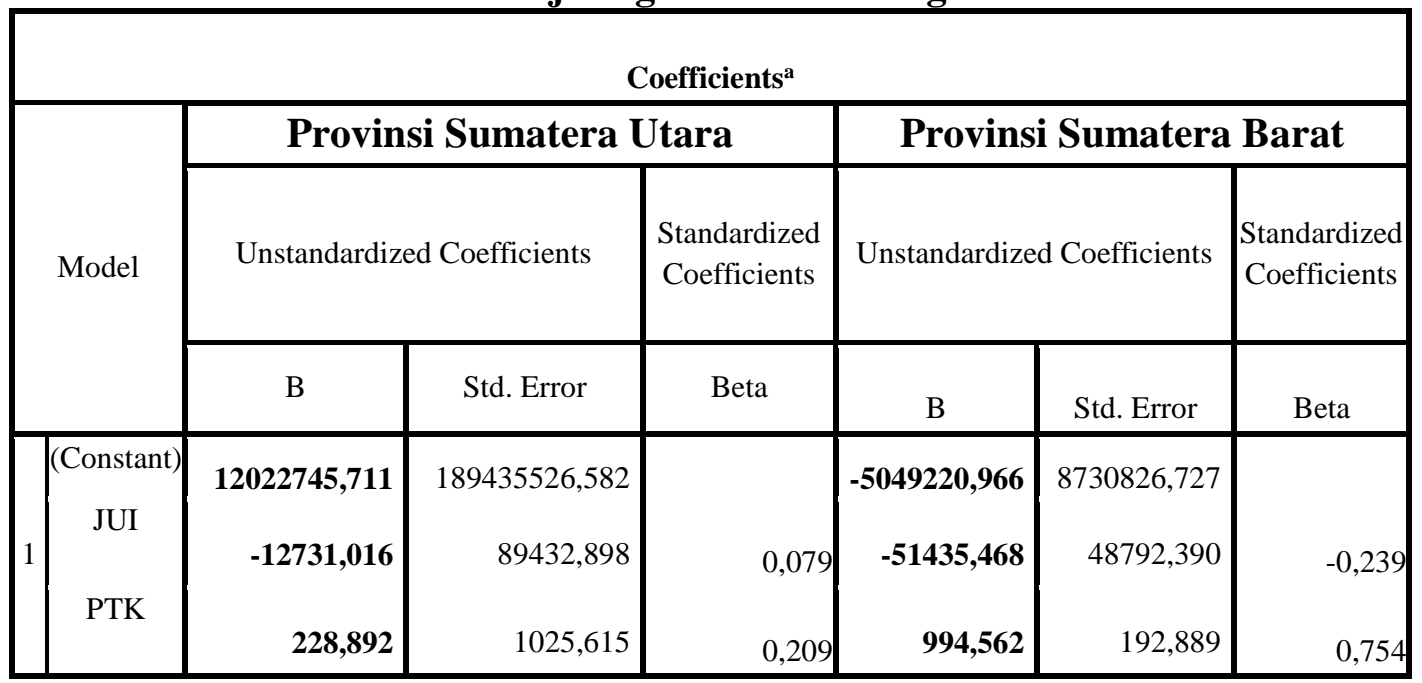

Sumber: OutputSPSS Versi 23, data diolah 
Berdasarkan tabel IV.7 di Provinsi Sumatera Utara diketahui bentuk persamaan regresinya sebagai berikut:

$$
\mathrm{PE}=\alpha+\mathrm{b}_{1} \mathrm{JUI}+\mathrm{b}_{2} \mathrm{PTK}+\mathrm{e}
$$

Sehingga persamaan regresinya :

$$
\mathrm{PE}=12022745,711+(-12731,016 \mathrm{JUI})+(228,892 \mathrm{PTK})+\mathrm{e}
$$

Persamaan regresinya dapat dijelaskan sebagai berikut:

a. Konstanta sebesar12022745,711, artinya apabila variabel jumlah usaha industri dan penyerapan tenaga kerja dianggap konstan atau 0 , maka pertumbuhan ekonomi di Provinsi Sumatera Utara sebesar12022745,711.

b. Koefisien regresi variabel jumlah usaha industri sebesar -12731,016 artinya apabila variabel jumlah usaha industri ditambah 1 persen dan variabel yang lain dianggap tetap maka pertumbuhan ekonomi di Provinsi Sumatera Utara menurun sebesar12731,016 persen.

c. Koefisien regresi veriabel penyerapan tenaga kerja sebesar 698,366 artinya apabila variabel penyerapan tenaga kerjaditambah 1 persen dan variabel yang lain dianggap tetap maka pertumbuhan ekonomi di Provinsi Sumatera Utara meningkat sebesar 228,892 persen.

Sedangkan di Provinsi Sumatera Barat diketahui bentuk persamaan regresinya sebagai berikut:

$$
\mathrm{PE}=\alpha+\mathrm{b}_{1} \mathrm{JUI}+\mathrm{b}_{2} \mathrm{PTK}+\mathrm{e}
$$

Sehingga persamaan regresinya:

$$
\mathrm{PE}=-5049220,966+(-51435,468 \mathrm{JUI})+(994,562 \mathrm{PTK})+\mathrm{e}
$$

Persamaan regresinya dapat dijelaskan sebagai berikut:

a. Konstanta sebesar-5049220,966, artinya apabila variabel jumlah usaha industri dan penyerapan tenaga kerja dianggap konstan atau 0, maka pertumbuhan ekonomi di Provinsi Sumatera Barat sebesar5049220,966.

b. Koefisien regresi variabel jumlah usaha industri sebesar $-51435,468$ artinya apabila variabel jumlah usaha industri ditambah $1 \%$ dan variabel yang lain dianggap tetap maka pertumbuhan ekonomi di Provinsi Sumatera Barat menurun sebesar 51435,468 persen. 
c. Koefisien regresi veriabel penyerapan tenaga kerja sebesar 994,562 artinya apabila variabel penyerapan tenaga kerjaditambah $1 \%$ dan variabel yang lain dianggap tetap maka pertumbuhan ekonomi di Provinsi Sumatera Barat meningkat sebesar994,562 persen.

\section{Uji Hipotesis}

\section{Uji Koefesien Determinasi (R Square)}

Hasil uji koefesien determinasi $\left(\mathrm{R}^{2}\right)$ dapat dilihat sebagai berikut:

Uji Koefesien Determinasi $\left(\mathbf{R}^{2}\right)$

\begin{tabular}{|c|c|c|}
\hline \multicolumn{2}{|c|}{ Model Summary $^{\mathbf{b}}$} \\
\hline \multirow{2}{*}{ Model } & Provinsi Sumatera Utara & Provinsi Sumatera Barat \\
\cline { 2 - 3 } & R Square & R Square \\
\hline 1 & 0,006 & 0,689 \\
\hline
\end{tabular}

Sumber:OutputSPSS Versi 23, data diolah

Berdasarkan tabel IV.8 di Provinsi Sumatera Utara diperoleh angka R Square sebesar 0,006 atau 0,6 persen. Hal ini menunjukkan bahwa persentase sumbangan pengaruh variabel independen terhadap variabel dependen sebesar 0,6 persen, sedangkan sisanya sebesar 99,4 persen dipengaruhi atau dijelaskan oleh variabel lain yang tidak dimasukkan dalam model penelitian ini.

Sementaraitu, Provinsi Sumatera Barat diperoleh angka R Square sebesar 0,689 atau 68,9 persen. Hal ini menunjukkan bahwa persentase sumbangan pengaruh variabel independen terhadap variabel dependen sebesar 68,9 persen, sedangkan sisanya sebesar 31,1 persen dipengaruhi atau dijelaskan oleh variabel lain yang tidak dimasukkan dalam model penelitian ini.

\section{Uji Koefisien Regresi Secara Parsial (Uji t)}

Hasil uji koefesien regresi secara parsial (Uji t)dapat dilihat sebagai berikut: 
ZULAIKA MATONDANG, M.Si

Uji t (Uji Parsial)

\begin{tabular}{|c|c|c|c|c|c|}
\hline & \multicolumn{5}{|c|}{ Coefficients $^{\mathrm{a}}$} \\
\hline & \multirow[b]{2}{*}{ Model } & \multicolumn{2}{|c|}{ Provinsi Sumatera Utara } & \multicolumn{2}{|c|}{ Provinsi Sumatera Barat } \\
\hline & & $\mathrm{t}$ & Sig. & $\mathrm{t}$ & Sig. \\
\hline \multirow{3}{*}{1} & (Constant) &, 063 & ,950, &,- 578 & ,573 \\
\hline & JUI & -,142 & ,889, & $-1,054$ & ,311 \\
\hline & PTK & .223 & 827 & 5,156 & ,000, \\
\hline
\end{tabular}

Sumber:OutputSPSS Versi 23, data diolah

Berdasarkan tabel IV.9 diketahui hasil pengujian variabel-variabel penelitian secara parsial di Provinsi Sumatera Utara adalah sebagai berikut:

a. Pengaruh jumlah usaha industri terhadap pertumbuhan ekonomi

1) Perumusan Hipotesis

$\mathrm{H}_{0}=$ Jumlah usaha industri tidak memiliki pengaruh terhadap pertumbuhan ekonomi.

$\mathrm{H}_{\mathrm{a}}=$ Jumlah usaha industri memiliki pengaruh terhadap pertumbuhan ekonomi.

2) Penentuan $T_{\text {hitung }}$

Dari output di atas diperoleh t hitung sebesar -0,142.

3) Penentuan $T_{\text {tabel }}$

$\mathrm{T}_{\text {tabel }}$ dapat dilihat pada tabel statistik dengan nilai $\alpha=0,05$, hasil diperoleh untuk $t_{\text {tabel }}$ adalah 1,699. (lihat pada lampiran $t_{\text {tabel}}$ ).

4) Kriteria Pengujian

a). Jika $\mathrm{t}_{\text {hitung }}<\mathrm{t}$ tabel maka $\mathrm{H}_{0}$ diterima dan $\mathrm{H}_{\mathrm{a}}$ ditolak.

b). Jika $\mathrm{t}_{\text {hitung }}>\mathrm{t}$ tabel maka $\mathrm{H}_{0}$ ditolak dan $\mathrm{H}_{\mathrm{a}}$ diterima.

Berdasarkan kriteria pengujian di atas dapat diketahui bahwa $t_{\text {hitung }}<t_{\text {tabel }}(-0,142<1,699) \mathrm{H}_{0}$ diterima dan $\mathrm{H}_{\mathrm{a}}$ ditolak.

5) Kesimpulan uji parsial jumlah usaha industri

Nilai $\mathrm{t}_{\text {hitung }}<\mathrm{t}_{\text {tabel }}(-0,142<1,699)$, maka $\mathrm{H}_{0}$ diterima. Jadi kesimpulan bahwa jumlah usaha industri secara parsial tidak memiliki pengaruh terhadap pertumbuhan ekonomi.

b. Pengaruh penyerapan tenaga kerja terhadap pertumbuhan ekonomi 
1) Perumusan Hipotesis

$\mathrm{H}_{0}=$ Penyerapan tenaga kerja tidak memiliki pengaruh terhadap pertumbuhan ekonomi.

$\mathrm{H}_{\mathrm{a}}=$ Penyerapan tenaga kerja memiliki pengaruh terhadap pertumbuhan ekonomi.

2) Penentuan $T_{\text {hitung }}$

Dari output di atas diperoleh $t_{\text {hitung }}$ sebesar 0,223.

3) Penentuan $T_{\text {tabel }}$

$\mathrm{T}_{\text {tabel }}$ dapat dilihat pada tabel statistik dengan nilai $\alpha=0,05$, hasil diperoleh untuk $t_{\text {tabel }}$ adalah 1,699. (lihat pada lampiran $t_{\text {tabel}}$ ).

4) Kriteria Pengujian

a). Jika $t_{\text {hitung }}<t$ tabel maka $\mathrm{H}_{0}$ diterima dan $\mathrm{H}_{\mathrm{a}}$ ditolak.

b). Jika $\mathrm{t}_{\text {hitung }}>\mathrm{t}_{\text {tabel }}$ maka $\mathrm{H}_{0}$ ditolak dan $\mathrm{H}_{\mathrm{a}}$ diterima.

Berdasarkan kriteria pengujian di atas dapat diketahui bahwa $t_{\text {hitung }}<\mathrm{t}_{\text {tabel }}(0,223<1,699) \mathrm{H}_{0}$ diterima dan $\mathrm{H}_{\mathrm{a}}$ ditolak.

5) Kesimpulan uji parsial penyerapan tenaga kerja

Nilai $t_{\text {hitung }}<\mathrm{t}_{\text {tabel }}(0,223<1,699)$, maka $\mathrm{H}_{0}$ diterima. Jadi kesimpulan bahwa Penyerapan tenaga kerja secara parsial tidak memiliki pengaruh terhadap pertumbuhan ekonomi.

Sedangkan hasil pengujian variabel-variabel penelitian secara parsial di Provinsi Sumatera Barat adalah sebagai berikut:

a. Pengaruh jumlah usaha industri terhadap pertumbuhan ekonomi

1) Perumusan Hipotesis

$\mathrm{H}_{0}=$ Jumlah usaha industri tidak memiliki pengaruh terhadap pertumbuhan ekonomi.

$\mathrm{H}_{\mathrm{a}}=$ Jumlah usaha industri memiliki pengaruh terhadap pertumbuhan ekonomi.

2) Penentuan $T_{\text {hitung }}$

Dari output di atas diperoleh thitung sebesar -1,054.

3) Penentuan $T_{\text {tabel }}$ 
ANALISIS PERBANDINGAN JUMLAH USAHA INDUSTRI DAN

PENYERAPAN TENAGA KERJA TERHADAP

PERTUMBUHAN EKONOMI

ZULAIKA MATONDANG, M.Si

$\mathrm{T}_{\text {tabel }}$ dapat dilihat pada tabel statistik dengan nilai $\alpha=0,05$, hasil diperoleh untuk $t_{\text {tabel }}$ adalah 1,699. (lihat pada lampiran $t_{\text {tabel }}$ ).

4) Kriteria Pengujian

a). Jika $\mathrm{t}_{\text {hitung }}<\mathrm{t}$ tabel maka $\mathrm{H}_{0}$ diterima dan $\mathrm{H}_{\mathrm{a}}$ ditolak.

b). Jika $\mathrm{t}_{\text {hitung }}>\mathrm{t}_{\text {tabel }}$ maka $\mathrm{H}_{0}$ ditolak dan $\mathrm{H}_{\mathrm{a}}$ diterima.

Berdasarkan kriteria pengujian di atas dapat diketahui bahwa $\mathrm{t}_{\text {hitung }}<\mathrm{t}_{\text {tabel }}(-1,054<1,699)$ maka $\mathrm{H}_{0}$ diterima dan $\mathrm{H}_{\mathrm{a}}$ di tolak.

5) Kesimpulan uji parsial jumlah usaha industri

Nilai $t_{\text {hitung }}<\mathrm{t}_{\text {tabel }}(-1,054<1,699)$ maka $\mathrm{H}_{0}$ diterima. Jadi kesimpulan bahwa jumlah usaha industri secara parsial tidak memiliki pengaruh terhadap pertumbuhan ekonomi.

b. Pengaruh penyerapan tenaga kerja terhadap pertumbuhan ekonomi

1) Perumusan Hipotesis

$\mathrm{H}_{0}=$ Penyerapan tenaga kerja tidak memiliki pengaruh terhadap pertumbuhan ekonomi.

$\mathrm{H}_{\mathrm{a}}=$ Penyerapan tenaga kerja memiliki pengaruh terhadap pertumbuhan ekonomi.

2) Penentuan $T_{\text {hitung }}$

Dari output di atas diperoleh thitung sebesar 5,156.

3) Penentuan $T_{\text {tabel }}$

$\mathrm{T}_{\text {tabel }}$ dapat dilihat pada tabel statistik dengan nilai $\alpha=0,05$, hasil diperoleh untuk $t_{\text {tabel }}$ adalah 1,699. (lihat pada lampiran $t_{\text {tabel}}$ ).

4) Kriteria Pengujian

a). Jika $\mathrm{t}_{\text {hitung }}<\mathrm{t}$ tabel maka $\mathrm{H}_{0}$ diterima dan $\mathrm{H}_{\mathrm{a}}$ ditolak.

b). Jika $\mathrm{t}_{\text {hitung }}>\mathrm{t}_{\text {tabel }}$ maka $\mathrm{H}_{0}$ ditolak dan $\mathrm{H}_{\mathrm{a}}$ diterima.

Berdasarkan kriteria pengujian di atas dapat diketahui bahwa $\mathrm{t}_{\text {hitung }}<\mathrm{t}_{\text {tabel }}(5,156>1,699)$ maka $\mathrm{H}_{0}$ ditolak dan $\mathrm{H}_{\mathrm{a}}$ diterima.

5) Kesimpulan uji parsial penyerapan tenaga kerja

Nilai $t_{\text {hitung }}>t_{\text {tabel }}(5,156>1,699)$, maka $\mathrm{H}_{0}$ ditolak. Jadi kesimpulan bahwa Penyerapan tenaga kerja secara parsial memiliki pengaruh terhadap pertumbuhan ekonomi. 


\section{Uji Signifikan Simultan (Uji F)}

\section{Uji F (Uji Simultan)}

\begin{tabular}{|c|c|r|r|r|r|}
\hline \multicolumn{2}{|c|}{ ANOVA $^{\mathrm{a}}$} \\
\hline \multirow{2}{*}{ Model } & \multicolumn{2}{|c|}{ Provinsi Sumatera Utara } & \multicolumn{2}{c|}{ Provinsi Sumatera Barat } \\
\cline { 2 - 6 } & $\mathrm{F}$ & Sig. & F & \multicolumn{1}{c|}{ Sig. } \\
\hline \multirow{4}{*}{1} & \multirow{2}{*}{ Regression } &, 037 &, $963^{\mathrm{b}}$ & $\mathbf{1 4 , 4 2 0}$ &, $001^{\mathrm{b}}$ \\
\cline { 2 - 6 } & Residual & & & & \\
\cline { 2 - 6 } & Total & & & & \\
\hline
\end{tabular}

Sumber:OutputSPSS Versi 23, data diolah

Berdasarkan tabel IV.10 dapat dijelaskan hasil pengujian variabel-variabel penelitian secara simultan di Provinsi Sumatera Utara adalah sebagai berikut:

a. Perumusan Hipotesis

$\mathrm{H}_{0}=$ Jumlah usaha industri dan penyerapan tenaga kerja secara simultan tidak memiliki pengaruh terhadap pertumbuhan ekonomi.

$\mathrm{H}_{\mathrm{a}}=$ Jumlah usaha industri dan penyerapan tenaga kerja secara simultan memiliki pengaruh terhadap pertumbuhan ekonomi.

b. Penentuan $F_{\text {hitung }}$

Dari output ANOVA di atas diperoleh $\mathrm{F}_{\text {hitung }}$ sebesar 0,037.

c. Penentuan $F_{\text {tabel }}$

$\mathrm{F}_{\text {tabel }}$ dapat dilihat pada tabel statistik pada signifikansi $=0,05$ dengan df $2=n-k-1$ atau $30-2-1=27$, hasil diperoleh untuk $F_{\text {tabel }}$ adalah 3,33. (lihat pada lampiran $\left.\mathrm{F}_{\text {tabel }}\right)$.

d. Kriteria Pengujian

a). Jika $\mathrm{F}_{\text {hitung }}>\mathrm{F}_{\text {tabel }}$ maka $\mathrm{H}_{0}$ di tolak.

b). jika $\mathrm{F}_{\text {hitung }}<\mathrm{F}_{\text {tabel }}$ maka $\mathrm{H}_{0}$ di terima.

Berdasarkan kriteria pengujian di atas dapat diketahui bahwa $\mathrm{F}_{\text {hitung }}<\mathrm{F}_{\text {tabel }}(0,037<3,33)$ maka $\mathrm{H}_{0}$ di terima. 


\section{Analisis Komparatif}

Hasil analisis Komparatif atau analisis komparasi atau analisis perbedaan dengan menggunakan uji repeated measures dapat dilihat sebagai berikut:

\section{Uji Repeated Measure}

Pairwise Comparisons

Measure: PDRB

\begin{tabular}{|c|c|c|c|c|c|c|}
\hline \multirow[b]{2}{*}{ (I) PROVINSI } & \multirow[b]{2}{*}{ (J) PROVINSI } & \multirow{2}{*}{$\begin{array}{c}\text { Mean Difference } \\
\text { (I-J) }\end{array}$} & \multirow[b]{2}{*}{ Std. Error } & \multirow[b]{2}{*}{ Sig. ${ }^{\text {b }}$} & \multicolumn{2}{|c|}{ 95\% Confidence Interval for Difference ${ }^{\mathrm{b}}$} \\
\hline & & & & & Lower Bound & Upper Bound \\
\hline 1 & 2 & $-19582,438^{*}$ & 968,316 &, 000 & $-21646,354$ & $-17518,521$ \\
\hline 2 & 1 & $19582,438^{*}$ & 968,316 & 000 & 17518,521 & 21646,354 \\
\hline
\end{tabular}

Sumber: Output SPSSVersi23, data diolah

Berdasarkan tabel di atas, kolom satu (angka 1) pada saat (i) Provinsi adalah 2 dan (j) provinsi adalah 2, atau ingin melihat perbedaan rata-rata pengaruh jumlah usaha industri dan penyerapan tenaga kerja terhadap pertumbuhan ekonomi antara Provinsi 1 (Sumatera Utara) dan Provinsi 2 (Sumatera Barat), didapat beda rata-rata adalah 19582,438 dengan kesalahan standar 968,316. Angka SIG sebesar 0,000 yang di bawah 0,05 menunjukkan sesungguhnya terdapat perbedaan antara Provinsi 1 (Sumatera Utara) dan Provinsi 2 (Sumatera Barat). Untuk lebih jelasnya dapat dilihat melalui garis plot sebagai berikut:

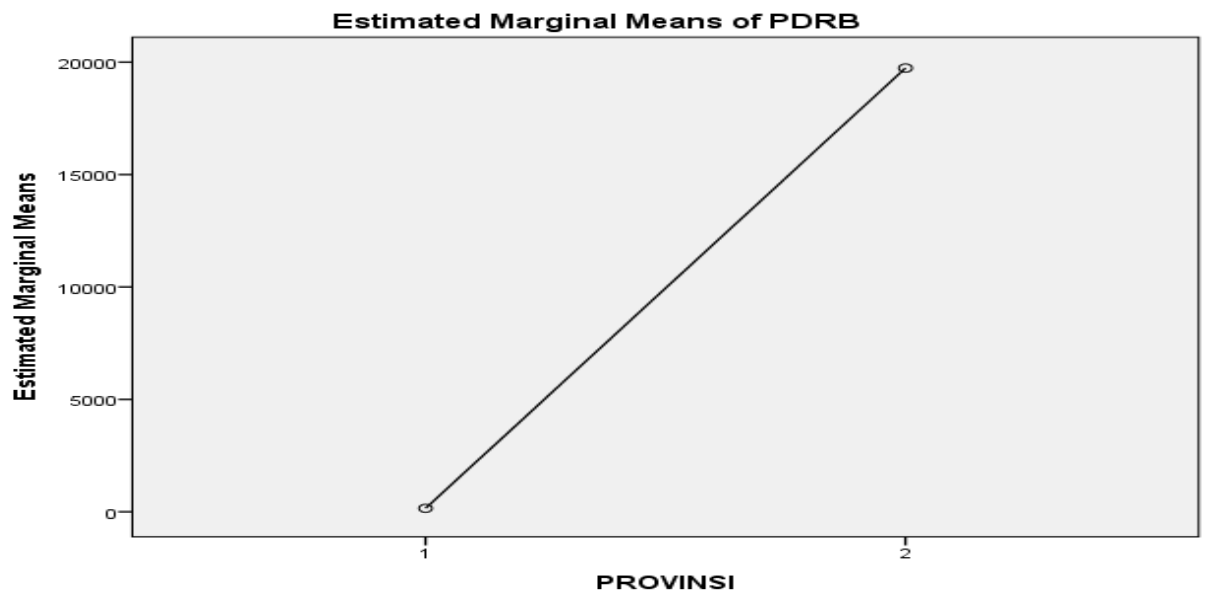

Dari plot juga dapat dilihat ketajaman kenaikan garis yang menunjukkan signifikansi kenaikan pertumbuhan ekonomi. Kenaikan tajam terjadi pada Provinsi 1 (Sumatera Utara) ke Provinsi 2 (Sumatera Barat). Hal tersebut 
menunjukkan pengaruh jumlah usaha industri dan penyerapan tenaga kerja terhadap pertumbuhan ekonomi tidak efektif di Provinsi 1 (Sumatera Utara), namun efektif di Provinsi 2 (Sumatera Barat).

\section{DAFTAR PUSTAKA} 2005

Iskandar Putong, Teori Ekonomi Mikro, Jakarta, Penerbit Mitra Wacana Media,

William A. McEachern, Ekonomi Makro, Diterjemahkan dari "Economics: A Contemperary Introduction” oleh Sigit Triandaru, Jakarta, Salemba Empat, 2000

Sadono Sukirno, Mikroekonomi Teori Pengantar, Jakarta, PT RajaGrafindo Persada, 2005

Rozalinda, Ekonomi Islam: Teori dan Aplikasinya pada Aktivitas Ekonomi, Jakarta, Rajawali Pers, 2014 